\title{
Thormation
}

Nordic Journal of Art and Research

ISSN: $1893-2479$

$\underline{\text { www.artandresearch.info }}$

\section{Applied Art: Innovative Thinking from a Material Perspective}

\author{
Anneli Hoel Fjærli ${ }^{1}$ and Ida Haugland ${ }^{2}$ \\ Oslo and Akershus University College of Applied Sciences
}

\begin{abstract}
The goal of this article is to form an argument implementing the seeming advantage of bringing in not just technological and theoretical avant-garde to the terms of innovation and development, but to invite the whole body into the forming of the future, thereby seeing the term innovation from a material perspective. While with increasing frequency, the art field today approaches subject matter that is primarily societal, we would like to introduce the potential for a mutual approach, focusing on the single human body and it's relation to the concrete artwork. Specifically, seeing the art field as a central part of the creation of engagement and progress that can instigate another form of efficiency and present an expanded understanding of what innovative activity can be, and how it is perceived and comprehended. We would like to debate an art form that takes the bodily, active, and relational focus-with its social context as a base and the starting point on the road toward societal consciousness and potential development. Looking at The Collectivity Project by Anri Sala and Olafur Eliasson as an example art project, this article takes its starting point in the following questions: How can participatory art and design projects, such as The Collectivity Project, promote bodily sensuousness as a tool in the forming of societal consciousness? And further, how does the material inter-relate with reflection, awareness and engagement?
\end{abstract}

Keywords: Materiality, embodiment, art, design, function, play, phenomenology, consciousness, The Collectivity Project, relational aesthetics, open-ended, branding, participation, co-creation

\footnotetext{
${ }^{1}$ Department of Product Design, Oslo and Akershus University College of Applied Sciences, PB 4, St. Olavs Plass, N-0130.E-mail: annelihoel@gmail.com

${ }^{2}$ Department of Art, Design, and Drama, Oslo and Akershus University College of Applied Sciences, PB 4, St.

Olavs Plass, N-0130.E-mail: idahaugland@ymail.com
}

http://dx.doi.org/10.7577/information.v2i2.732

199

Volume 2, No 2 (2013) 


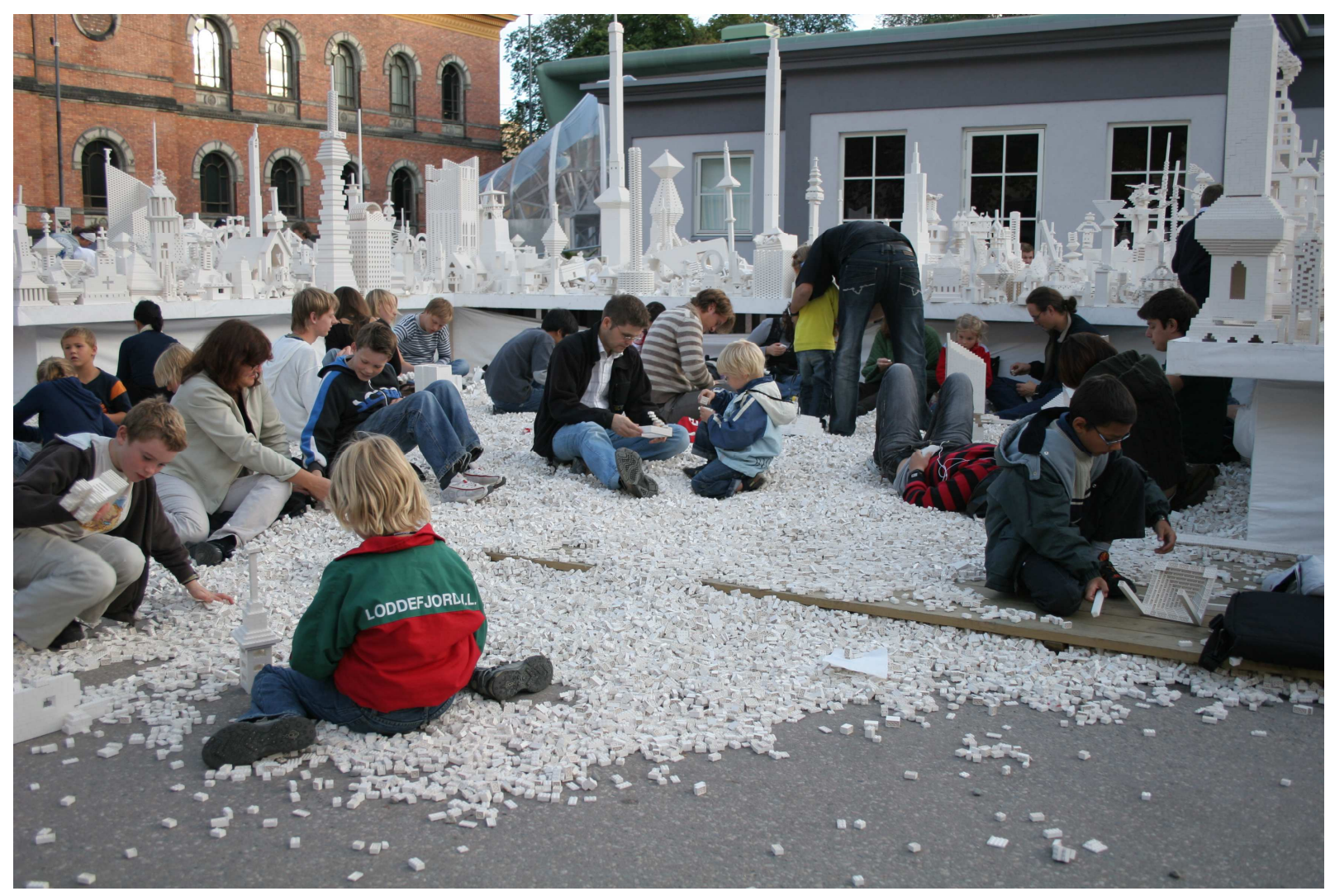

The Collectivity Project by Anri Sala and Olafur Eliasson. Photo by Børge A. Roum. @Creative Commons BY-SA 4.0

\section{Introduction: Art, function and innovation}

Although more or less visible or obvious throughout history, art has always had a function. Architecture explains this function to us: we all know that beautiful and magnificent buildings, both old and new, exist throughout the world. Many of these buildings are actual works of art. Nonetheless, there is probably not a single building in the entire world that was not built for a particular reason or intent. The people who use these buildings—-whether for living, praying, eating, exercising, protection, or just shelter-judge them primarily from a functional perspective. There is no way to make a judgment regarding a building if you do not know what kind of service or function the actual building is satisfying (Gombrich, 1995).

Using the example of an art project that revolves around architecture, this article focuses on the relationship between art and function. With a foundation and starting point in the art field, it focuses on the ability to look at developing processes from different angles. By looking at an example art project, The Collectivity Project, as a case study, this article debates what kind of innovative qualities or values can be found in the activity of the applied aesthetics, and how this can show the applied aesthetics as a possible way of developing new ideas, structures, and solutions through active, creative work. The content 
discusses societal development - because it relates directly to the consumers of the society and their needs, innovative activity becomes an important aspect. When thinking in innovative terms, along with the development, it is important to keep these consumers in mind-and not only in mind, but also in terms of the bodily. From both social and aesthetic perspectives, this article seeks to answer:

How can participatory art and design projects, such as The Collectivity Project, promote bodily sensuousness as a tool in the forming of societal consciousness? And further, how does the material interrelate with reflection, awareness and engagement?

The term societal development can have many approaches, including economy, politics, climate, etc. This article seeks to present a 'cultural materialist' perspective on how to think in terms of innovative activity in society. It is important to state that the article does not seek to compete with the already established perceptions of innovation or societal development, nor does it want to redefine these terms in any way. Instead, it seeks to present another perspective on where macro-level development and creative processes can have their starting point in the context of innovative activity and societal development; the sensuousness, the bodily experience, and the human closeness to its surroundings are set in relation to the more general societal macro-perspective.

The artists Olafur Eliasson and Anri Sala started The Collectivity Project, in 2005 at the Tirana Biennial, Albania; it later moved to Copenhagen and ended in Oslo, Norway, in 2006. Inviting people to build their future dream building or city, the project involved thousands of kilos of white LEGO bricks in an open public space. In Oslo, the project was located at Tullinløkka, an open space that represents an area of discussion around the localization of different museums of the city, and the question of the National Museum's right to use this area for expansion and to improve their facilities. The discussion has been going on for years. The area's history of use shows both an ice skating rink and a playground, and the potential expansion of the National Museum to be built here, has resulted in multiple reactions against what many have defined as a plan pertaining merely to the culturally high class citizens, thereby excluding part of the community's participants (Nordengen, 2007). Then, after years as a parking lot, Tullinløkka was suddenly filled with Lego bricks via The Collectivity Project, which invited people to participate in a building activity and gave them the opportunity to create a visual representation of their dream situation for the area. At first glance, The Collectivity Project might, to many, seem like a mere playground for brick building — an isolated activity, not contributing to anything in particular, other than the immediate and temporary fun and well-being of the individual participants. How can such a project, clearly related to fantasy and play, in any way actualize development or innovative thinking from a material approach? To discuss this matter effectively, we need to look at the term "innovation," as it relates to this article. The word "innovation" comes from the Latin innovare, which means renewing, or creating something 201 
new. Ideation is central in this aspect, as it stands for the process of creating new ideas. Nonetheless, associate professor Erik Lerdahl states that innovation is not established before the idea is implemented and integrated in an organization (Lerdahl, 2007, p. 300). Specifically, before it is considered an innovation, it has to be applied, taken into use or production that answers a certain need or problem, and value of some form has to have been created. The result and benefit driven way of thinking places a considerable focus on concrete and observable results-efficiency, rationality, and profit. The means of the process is given less space, as the competition between businesses or goods are normally cost and market driven. The connections of innovation and economic value and increase are closely linked to the identification of needs from consumer groups, and a circle of production of beneficial and efficient ideas and merchandise is established. This is one reason why innovation is so often closely associated with high technology, quick growth, and modern radical impulses (Foros \& Vetlesen 2012, p. 244f). It has become synonymous with sense and reason, which in itself is a good thing, since it can variously instigate technological development, knowledge growth, and enhance numerous forms of patterns and methods. Nonetheless, this article debates another approach to thinking in innovative terms, which relates to new methods of development, where the process is a central aspect, and the goal is not necessarily specified in advance, although it is still determined within defined themes or issues. As innovative thinking and development often start with creative thinking and abstract ideas, there are obvious parallels to the process of play, which becomes a central perspective in our approach toward The Collectivity Project.

\section{The potential of play - structures of creativity and development}

The philosopher Friedrich Schiller explains that the need for and the ability to play and imagine things is what separates man from animal (Schiller, 2008). He defines our curiosity toward illusion as the main expansion of the human mind, and as a crucial step toward culture (Schiller, 2008, p. 95). From this perspective, sticking to reality would be parallel to limiting our cognitive skills. The philosopher HansGeorg Gadamer has similar views; playing has both a bodily and a reflective aspect to it. The sensuous and bodily activity of play and fantasy is not comprehensible with fooling, lying, or cheating, but rather connected to the development and creation of new and understandable structures (Gadamer, 2004). Historically, this has been exemplified by traditional gender patterns such as boys playing with cars, machines, and toy swords - thereby achieving the skills to protect themselves and provide for a potential family; and girls playing with dolls—-thus preparing for their likely future role as mothers. The role-play, a pretending game, is not merely fantasy, but it relates to a future reality of independence and responsibility (Sigsgaard \& Varnhild, 1982). Both the theories and the former example imply that the line between reality and fantasy is blurred; playing is not constructed or artificial, but it exists as a deep, embodied biological and anthropologic instinct in every human being (Gadamer, 2004). Let us clarify by using an 
example, a picture of a friend, or someone random from a newspaper photo. If a needle is pierced through the eyes of the depicted person's face, would we not have a very different feeling if the same needle had pierced a different area of the picture, say the background? Art historian Ernst Gombrich highlights a human feeling of aversion against destroying a picture of other human beings or living creatures. He calls attention to the fact that we all carry the absurd feeling that destroying the picture will also hurt the person in it (Gombrich, 1995, p. 20). The visual aspect has a kind of power over us that we automatically connect with the involvement of something bodily or sensuous. The same thing happens when putting on a maskwhether it is part of a ceremony in a primitive tribe in the jungle, an actor participating in a play, or a couple of kids playing together-when putting on a mask, both our mind and body transform into the clown or the bear presented by the mask, and the boundaries between the ceasing of reality and the beginning of fantasy become blurred (Gombrich, 1995, p. 23).

The French philosopher Jacques Rancière furthers the discussion by arguing that even reality primarily has to be in a state of fiction before becoming real (Rancière, 2012, p.50). Hence, he makes it clear that even the best ideas for development and innovation have to be fictionalized before they exist in real life. This demonstrates the potential to process the relationship and the possibility between the imaginary and the real in the creativity of play. It is in this area of thought that David Gauntlett, Professor of Media and Communication at the School of Media Arts and Design in Westminster, also states that we need to reconsider what the term creativity actually represents; he calls for attention to simple ways of thinking, solutions, and development (Gauntlett, 2011, p. 74). The American writer and lecturer, Susan Cain, states similar views on the location of the core of creativity. Through strict research on introversion, she rejects the unambiguous relationship between being the loudest speaker and having the best ideas or solutions to a problem. When looking at the lives of the most creative people, she explains that psychologists find that these people are very good at exchanging and advancing ideas, but also that, for the most part, they develop these ideas when they are alone. Among others, Cain mentions Charles Darwin and Steve Jobs; she says that because these artists were able to develop their ideas through independent activity, they made important innovations. Without their opportunity to work alone, we would not have the Apple computer, Einstein's theory of relativity, or even van Gogh's sunflowers, Cain claims (Cain, 2012, p. 21.).

This introvert method of describing the nucleus of creativity is obviously not related to The Collectivity Project in a logical way_-just look at the name; collectivity. The Collectivity Project presents a focus on common action and creation. Still, projects like this very often start with the thoughts of a single artist on a particular subject, him or her alone laying a foundation for further action. It relates to the theory of relational aesthetics, decribed by Nicholas Bourriaud - a way of focusing on art as an exploration 
of, or the making of different encounters or moments of sociability and communication. The artist lets the audience develop the reflections further, through their actions with the artwork, making them co-creators, and thereby allowing them to control the development of the artist's intention. Not to underestimate the single human being's creative feature, nor the artist or the co-creator, and not to underestimate the possibility of them creating a common reflection and development that can benefit the community or others - this demonstrates that introvert creativity can become extrovert action. Cain compares it to the example of leader figures in all big religions; they are all seekers who turn to themselves and get profound epiphanies and revelations, which they bring back to the rest of the community; just like play, development starts with the single individual (Cain, 2012). Creativity is linked to everyday life and the single bodily mass, which in the next step can become critical in a larger context.

Looking at these perspectives on creativity, this article also suggests that creativity should not only be defined based on the activity itself-how simple or advanced a thing or a process looks, or how simple or innovative the actual methods of work are-it should rather be defined based on the processes and the results it generates and/or to which it contributes. Creativity, as Gauntlett states, needs to be linked to everyday life and the consumers of society, which is an additional prerequisite for development and innovation (Gauntlett, 2011).With the link between the imaginary play with the Lego bricks and the actual situation for Tullinløkka, The Collectivity Project operates in a kind of balance between reality and fiction, which creativity and actual development represents. As a close connection to play, the project uses one of the best-known toys of the world-Lego bricks, which also has its reference to play through the name Lego, LE(g) GO(dt), meaning play well (Lipkowitz, 2009). By stacking the bricks to form personal individual houses and buildings, the fantasy and creativity of the participants are put into play. The activity is physical and individual. While the bodily and sensuous focus does not exclude other activities and processes, looking at the situation from the bodily and sensuous perspective clarifies this proposition.

\section{Development from the bodily point of view}

Each in their own way, the $20^{\text {th }}$ century French philosophers Gilles Deleuze, Félix Guattari and Maurice Merleau-Ponty, show that there is a significant amount of knowledge in sensuous movement. But while the post-structuralists Deleuze and Guattari state that art expresses an experience only attainable through sensuousness, which they describe as non-organic or non-muscular athleticism - what they call affective athleticism (Deleuze \& Guattari, 1991, p. 491ff) - Merleau-Ponty sees the dynamic body's contribution to knowledge and reflection from a phenomenological perspective: 
Fjærli and Haugland: Applied Art

The permanence of my own body (...) is not at the extremity of some indefinite exploration; it defies exploration and is always presented to me from the same angle. Its permanence is not a permanence in the world, but a permanence on my part (Merleau-Ponty, 1962, p. 90).

What he means by this is that you cannot move around your own body, but your body can move around different objects and artifacts. It is the body's position in a room that defines the perspective in relation to, for example, a chair (Merlau-Ponty, 1962, p. 98). Walking around the chair will show a number of different angles and perspectives. Touching the chair or sitting on it, brings different conceptions of the chair as well. The example indicates that movement and close contact with concrete surroundings generates a more complete understanding of the perceptible world—one has the possibility to take different positions, both bodily and intellectually.

The theories emphasize that a body is not something that we have or do not have. When thinking, the mind is always connected to our sentient body, which is the only thing we can feel and know the world through - we are never detached from our own biological materiality, nor can we switch or change it (Tin, 2011, p. 33, 208). This indicates that our living body has to have access to the outer world to be able to think and reflect. It happens through our senses - and this is exactly why we have to see the body as an integrated part of man, as a whole, rather than contemplating it as an object limited to physical skill. For the living body to articulate meaning, action has to stand as a catalyst, and the creation of meaning requires interplay. For example, the fact that instruction manuals are frequently written by people who have never touched or even seen the object they are describing in real life, is in many cases, the reason why the manuals are so hard to understand. There is a missing link between the producer and the user. On the other hand, looking at the work of a painter, this relation will look different; the painter starts his work of creation by laying the first stroke of color to his or her canvas. The artist develops the motif through continual relations between new colors and forms to the canvas, being in close contact with the object of work. Still, for the result to be fully successful, the artist has to put down the paintbrush and take a few steps back to see the creation from a distance, where new perspectives and ideas develop. The procedure is not merely theoretical or practical, but an alternation between impression and expression, which together creates a whole (Tin 2011, p. 203f). The different perspectives that the painter takes on are interdependent, not separated. In terms of The Collectivity Project, this highlights a question of what can happen in the process of stacking Lego bricks to form buildings. What kind of positions do the participants take on in the building, evaluating, disassembling, and rebuilding of their architectural ideas? What kind of perspectives develop in this close contact with the Lego bricks?

Norwegian cultural philosophers Per Bjørn Foros and Arne Johan Vetlesen (2012) present interesting perspectives on this subject. In their book Angsten for oppdragelse - et samfunnsetisk 205 
perspektiv på dannelse (transl. The Anxiety of Upbringing) (Foros \& Vetlesen, 2012), under the section Being in the World, they explain how both pedagogical and political labor is concerned with linking everyday doings and services with their overall aspirations and ideals. Still, the authors make it clear that not every awareness process or reflected action can have its origin from the above institutions. If history has taught us anything, they maintain it is that politics has its limits and boundaries, and that state business, public bureaucracy, and large-scale programs do not necessarily lead down the intentional or right path. In contrast to this perspective, they imply that a lot can grow from the other side of the fence. They point to the importance of a base and starting point in seemingly small, yet concrete, everyday choices. These everyday choices provide an opportunity to link actions and meanings to more superior perspectives from the bodily point of view; such as turning off the bedroom lights in the daytime, because of an awareness of the need to reduce the amount of energy consumed in the world today. They present a 'bottom up perspective', where the small, bodily, and intimate based experiences and choices can eventually become political and have a substantial influence on social change (Foros \& Vetlesen, 2012, p. 216).

This a contextualizing framework as to what the participants of The Collectivity Project are actually contributing to, and how the boundaries between the fictional and actual development and discussion at Tullinløkka are being conducted. The building activity in The Collectivity Project reflects much more than the individual creativity of stacking together one's dream museum or building. Through close contact between what is happening both between the white bricks and the people building, and between the people building and the museum debate, it also creates an opportunity for a link toward the ongoing discussion revolving around Tullinløkka. It mirrors the ongoing debate of what is to be built in this open empty space, and it creates an opportunity for a connection between the participants' Lego houses and the real dilemma: What do we want to build at Tullinløkka? Important aspects of how the development toward new ideas or solutions can start appear in these processes.

\section{The Collectivity Project: Material, body, and consciousness}

As The Collectivity Project is directed toward making the participants part of the actual museum debate, the material becomes prominent. How does the material inter-relate with reflection, awareness, and engagement in this art project? Lego is a well-established and well-known toy product. When looking at the brand's development, it is easy to see that the company's approach toward the market today has increased, in both variety and amount. For the sake of market prices and competition, their constant new themes, frequently linking with well-known brands such as Spiderman, Ninja Turtles, and Despicable Me, can in many ways be comprehended as a step away from their own uniqueness or distinctiveness. Their 
pink line, made first and foremost for girls, can be perceived first as old fashioned, in the sense of separating ways of play by gender, and second, as a step away from their original principle of putting together geometric figures. Nonetheless, looking at the basic principles of Lego-square bricks to form new figures—-the product appears timeless.

Since The Collectivity Project uses white bricks, this statement of timelessness is even stronger, and this places the toy product in a more general category, suited for a work in the art field. By using this known toy product, the art project works with a material that puts the children's imagination in front (Lipkowitz, 2009); the user decides what the results should be or which story to play out. This is further enhanced by the fact that it is easy to stack and disassemble, which opens up for endless possibilities of development and change along the way. Just like drawing or playing with a doll, there are few limitations for a fantasy or story to play out. The basic structures of which the material and the activity consists, offer the user the ability to adjust and develop the stacking onto their creative level—it follows the user's development through life, enhancing the complexity of the building activity at the user's individual pace. This demonstrates the product's open-endedness on many levels- the person stacking and organizing the bricks is the one who decides how this process is going to end, when it is going to end, and what will come of it. It represents a way of playing that can relate fully to the playing children or person's aspirations, interests, and wishes - their creativity and knowledge. As it puts the active participant's cognition, focus, and style in the center of the creative process, it opens up for the thought of co-creation, making the individual thoughts and reflections important. As the Lego example is not exclusive, on a general level, it relates to the active creation through materials where the bodily focus becomes clear.

Highlighting the aspect of consciousness as it relates to the project, the actual Lego bricks stand as an example of how the connection to our outer world works. While Foros and Vetlesen discuss the ability to create connections by displaying everyday life in a larger context, several theorists emphasize the benefit of involvement of the art field in this matter, thus demonstrating how the relationship between art, social, and societal matters is evident. French art philosopher and curator, Nicolas Bourriaud, and his subject peer, philosopher Jacques Rancière, are central voices in the context of the applied arts in relation to societal preferences. Their perspectives can complement the understanding of how the individual and the environment he or she is a part of relates to each other in terms of consciousness, and thus propose The Collectivity Project's meaning in a larger context; are we producers or consumers of our own environment? How do we relate to our own surroundings? 


\section{Creating connections: Inter-relational space}

Rancière states, "Art no longer wants to respond to the excess of commodities and signs, but to a lack of connections" (Ranciére, 2004, p. 90). Bourriaud means this is where art becomes political, (Bourriaud, 2006, p. 21), and emphasizes that the way we live our lives today has changed tremendously in the last decades. Modern urbanization has developed a rapid and overwhelming expansion of social and human conjunction and individual mobility, the general mechanization of social relations has gradually reduced the inter-human and relational room. Machines and mechanical processes now do the work that previously offered humans the opportunity for the exchange of ideas. Even face-to-face meetings between peoplereal relations - are being objectified, Bourriaud says $(2006$, p. 21, 10). The imbalance seems to touch upon the theme of proximity - to ourselves, the relation to others, and to our material environment (Bourriaud, 2006: 10). Represented as a reification or commodity, human relations become part of market-driven processes. Bourriaud compares the current society's organization around efficiency and expansion with a freeway; it allows us to travel faster, in a more adequate or sufficient way, so we can reach our goal even quicker. Still, he emphasizes that this freeway mode of living also has the adverse ability to convert and transform its users into nothing more than mere consumers of time, space, and material (Bourriaud 2006, p. 9). His proposition seems to fit the template presented by Vetlesen and elaborated through research ascertaining the inverse proportion of the coherence between happiness and prosperity/wealth (Vetlesen, 2012). Vetlesen states that the ability to reflect upon single matters in a non-abstract way, connecting thoughts and actions, disappears in this race for the next assignment or goal, making people solely consumers of society's practice (Vetlesen, 2012). Similarly, art historian Tanya Harrod calls attention to the fact that today, a considerable majority of consumers, in proportion to producers, point toward a troubling future, variously concerning the economy, environmental issues, and the general development of society (Harrod 2004, p.40ff).

It is in this matter that Bourriaud implies the need for other forms of social relations, which are no longer presented as reified or as a commodity. As philosopher and sociologist Zygmunt Bauman points to the critical importance of our basic ability to be emotionally affected by what is being done to other living creatures and surroundings (Foros \& Veltesen, 2012, p. 243; Bauman, 1993, p. 247ff), what comes within sight is a gap between the modern world and the people living in it. With the increasingly prevalent environmental, economic, and social challenges in our society today, the question of affectedness is noticeable; not grounded exclusively in the matter of being affected, but this affectedness in connection to being able to trigger and instigate reflection and raise consciousness and engagement. This can further stimulate the active individual participant, and create motion toward a society of both individual and shared consciousness and development. By demonstrating how being close to the material of action can 
develop thoughts on sustainability and encourage values closely connected to an innovative way of thinking, The Collectivity Project is "playing out" these issues.

Lego bricks are a product of design, and in the design field, making long lasting environmentally friendly products is considered a standard (Gulden \& Moestue, 2011). Indeed, the goal of producing long lasting products is as much a question of the connection between the product and the consumer as it is about the actual material quality. Cultural theorists Celia Lury and Scott Lash, describe this through branding, what they see as a virtual reality (Lury \& Lash, 2007). We become emotionally attached to a product and give it a personal value through our activity and experience with it. Lury and Lash maintain that this creates a feeling of closeness and ownership to the actual object of use, which in the best-case scenario will affect the product's lifetime in a positive way (Gulden \& Moestue, 2011). Lego bricks have a successful history in the toy design field, as they are still being passed down through generations. Even though the styles have changed, the bricks are still seen as valuable. Through memory and alternative ways of building, the users have become attached to them. Their open-endedness makes them timeless and defines a quality in terms of duration, which creates an emotional attachment that prevents the users from throwing them in the garbage. This long lasting ideal through which the design field frequently operates, and that Lego explicitly exemplifies, demonstrates that emotional connections to our surroundings makes us aware of the necessity to engage in and take care of these things: We dwell on them (Sennett, 2009, p. 24). This leads to a potential contradiction, implied by Bourriaud, to the discussion of the unconscious and volatile relationship between man, material, and environment. With this insight, the Lego design branding - in spite of the fact that it is a part of a field related to production, sales, marketing, and commodity, all of which Bourriaud mentions as challenges — can actually stand as an example of a way to think and act in the process of societal development and innovative terms. The brick building is not merely a process toward finishing a work of art or a fantasy building at Tullinløkka. The dwelling, development, awareness, and ownership that this activity generates are just as important as the actual result of the process. For the successful finished product to be carried out into real life-fantasy, creativity, and dwelling need to come first—just as Schiller and Gadamer propose, and as Lerdahl states, this is essential to making innovative activity possible.

In this way, the phenomenon of branding can demonstrate the effect that a material or an object can have on us, and The Collectivity Project's Lego bricks have the ability to show this connection between material, body, and awareness. Nonetheless, put into the context of The Collectivity Project, branding must be seen in a broader context. Stating its message with the help of Lego, the art project uses material or objects with which people have a positive connection, and creates connections based on, or through this connection. It truly demonstrates the potential that resides within the close contact and 
interaction between body and material, as the ownership is not just linked to the actual object, but to the subject matter of the process - the bonding turns co-creation into co-participation. This is where societal matters become actual, and in this case, at Tullinløkka in particular. Since Lego bricks and the act of playing are connected to thinking forward through creativity—both according to Cain's introvert creative human being and between the introvert and society—so too is the meaning of The Collectivity Project. Although this type of branding does not signify an attitude of attempting to affect someone in a certain way, it has the ability to represent a process based on emotions and attitudes toward our surroundings. This, in turn, makes us aware and co-responsible, able to make choices because we are an active part of these processes, thus making us see that these processes indeed affect us. Because the activity and the reflections raised are immediate, direct, proximate, and concrete, even when sitting alone in the pile of Lego bricks, we are participating in a potential development that is just as important for innovation as the macro-mechanisms in society. This is where Bourriaud's relational aesthetics in the arts and the branding thoughts from the design field join together in a "symbiosis" of awareness between man and his surroundings; to brand something is to put our mark on it, which is, in a wide context, exactly what is being done using white Lego bricks at Tullinløkka.

\section{Moving towards the end}

As is clear through the above discussion, The Collectivity Project touches upon time, space and materialall components that Bourriaud saw distorted in connection to consumerist distancing, lacking conscious cognition (Bourriaud, 2006, p. 9f). But instead of merely being users and/or consumers of time, space, and material, we believe that the participants of The Collectivity Project are given the possibility of becoming practitioners, producers, and co-creators. From this perspective, the gap between the individual microperspective and the urban development's macro-perspective can be shortened. It emphasizes the core of this discussion; how social art projects based on participation and direct contact with the material, can engender societal consciousness and material reflection.

With these processes, a democratic thought forms around the project, and the title of the project becomes clear in its intention, collectivity. As different individuals form their pieces of work through stacking, they are simultaneously participating in a whole, which can depict the different thoughts and wishes of the city's active population for the area. The people, who are actually going to use the future facilities of the area, get an opportunity to have a say in how it is going to look and how it is going to be used. Furthermore, when or if this is further implemented into reality, the participants will have the ability to interfere more consciously, and to be more aware about the situation-not as consumers, but as individual co-producers of a collective practice. This is where art can show its extended potential, and 
signifies its values as connected to the innovative society: to visualize society, to raise debate, to dialogue subjects, and to establish the link between what is and what can be. The relational, participatory, and political implications are contributing to a placement of art in context, and development through art—by people's interactive fantasies and ideas of a museum, made real in an empty museum ground. With a look back on the concept of innovation, as presented by Erik Lerdahl, although this is from a different perspective than the typical habitual innovative thinking, we can clearly see the applied aspect, the creation of values, and a process that answers to a certain need or problem in The Collectivity Project.

This article suggests the potential of art and design when put into a context, the creative process as a tool, or way of working toward development, and the creation of innovative thinking or values. In the following, we summarize the main suggested emphases: The Collectivity Project connects art and play, which makes the brick building no longer a solely individual process. Through the white color of the bricks and the location of the workshop in a common space, Lego changes from a toy meant for the private sphere and the Lego brand's intentional practice, into a more general, artistic material relating to society. In this transformation, a different curiosity arises-one of what others are building. It is in this symbiosis of art and play that the potential for development becomes clear-through active, visual, cognitive, and contextual work.

Innovation and societal development is important because it relates directly to the consumers of society and their needs. When thinking in innovative terms, it is important that we keep these consumers in mind, and take them with us along the way. We have debated that social development and innovative thinking can be based on certain values, which differ from the common perception of these aspects development can be based on a practice of concrete creativity. Connected to the natural affectedness that art engenders; affectedness revolves around acknowledging the consequences of our actions, and that these are dependent on how close we are to the actual consequence. Closeness engenders responsibility and critical approaches, which are exactly why being close to what we produce, consume, and surround ourselves with is essential. It represents a natural and logical way to think ahead, and can thus propose an important aspect in the forming of values connected to conscious development and innovative thinking relating to different issues. Through their theories, Schiller and Gadamer reject the genius approach toward the creation of something new, and instead call for attention to simple ways of thinking solutions and development (Gauntlett 2011, p. 74). Because the dwelling, development, awareness, and ownership that this activity generates can be just as important as the actual result of the process, there can be an opening for art projects such as The Collectivity Project to be considered meaningful in a societal context. Highlighting a possible approach to developing processes from a material perspective, the single playing body is set in relationship to bigger processes. 
This bodily interaction with the material is noticeable. It becomes a meeting point between the individual and his or her surroundings. Because things and materials are solid and lasting, we can dwell on them in a way that we cannot do with a flowing volatile discussion (Sennett, 2009, p. 24). Here, we find an advantage in the connection between man and material, an extended possibility for cognitive development. This has a resemblance to the theories on play, where the exploration of a material or object is a means toward understanding and developing, through seeing possibilities and limitations. Together, these implications show us that things, materials, or surroundings are essential to how our body thinks and makes progress - the body and its surrounding material are interdependent. In terms of showing how it can reflect material approaches toward how and where innovation can start, and what it can be, it collectively creates a springboard for the applied arts.

The Collectivity Project thus demonstrates that art is not closed off from our daily life, and is not merely an object of study, something to look at, safely stored inside museums and galleries (Dewey, 1934). Art is sensuous and the recipient contributes to this process. Placed into a theoretical or philosophical context, with the potential of Lego bricks for activity and play, The Collectivity Project could be said to represent what professor in pedagogy Jorunn Spord Borgen calls a post war pedagogy (Spord Borgen, 1995). This among other things implies playing your way toward results, as the building activity relates both to the imaginary and the real. The art project depicts the arts as an open field, where creative experimenting can generate ripple effects, a reference to a connection between aesthetic processes on the one hand, and the ability of art to have a societal responsibility and create room for discussion and political conditions on the other. By understanding art and design as experiences, as consciousness, and as participation, rather than just as artifacts, we can avoid giving defining characteristics of art that exclude potential artworks from being fulfilled as just that. This makes it possible for art projects such as The Collectivity Project to be seen as a part not only of society's cultural aspects, but also as a part of its developing processes in other fields. This is where new perspectives on the creation of conscious social development and innovative values can start.

\section{On the contributors}

Ida Haugland holds a MA degree in Art and Design Didactics, and is currently teaching Art, Craft and Design subjects at Majorstua secondary school in Oslo.

Anneli Hoel Fjærli holds a MA-degree in Product Design. 
Fjærli and Haugland: Applied Art

\section{References}

Anderson, R. L. (2004). Calliope's sisters. A comparative study of philosophies of art. (2nd ed.). New Jersey: Pearson Prentice Hall.

Bauman, Z. (1993). Postmodern ethics. Oxford: Blackwell.

Bishop, C. (Ed.). (2006). Participation. Documents of contemporary art. London: Whitechapel Gallery.

Borgen, J. S. (1995). Formingsfaget i et oppdragelses- og danningsperspektiv. In B. Tronshart (Ed.),

Formingsfagets egenart: en artikkel- og essaysamling. Notodden: Høgskolen i Telemark.

Cain, S. (2012). The power of introverts in a world that can't stop talking. Center Point Publications.

Cialdini, R. (2011). Påvirkning: teori og praksis. Oslo: Abstrakt Forlag.

Gauntlett, D. (2011). Making is connecting: The social meaning of creativity, from DIY and knitting to YouTube and Web 2.0. Cambridge: Polity Press.

Glissant, È. (1990). Poetics of relation. In C. Bishop (Ed.), Participation. Documents of contemporary art. London: Whitechapel Gallery.

Gombrich, E. H. (1995). Verdenskunsten. (2nd ed.). Oslo: Aschehoug.

Gulden, T., \& Moestue, C. (2011). A psychology based design tool, towards sustainable consumption through extending the product lifetime. In N. F. M. Roozenburg, L. L. Chen \& P. J. Stappers (Ed.), Diversity and Unity: Proceedings of IASDR 2011, the Fourth World Conference on Design Research. October 31 -November 4, Delft, The Netherlands.

Harrod, T. (2004). Craft today contemporary concerns. In M. K. Mitchell \& S. Brown (Ed.), The beauty of craft: A resurgence anthology. Chelsea: Green Books.

Lerdahl, E. (2007). Slagkraft: håndbok i idéutvikling. Oslo: Gyldendal akademisk.

Lipkowitz, D. (2009). The LEGO book. London: Dorling Kindersley.

Lury. C., Lash, S. (2007). Global culture industry: The mediation of things (pp. 1-15). Cambridge: Polity.

Merleau-Ponty, M. (1962). Phenomenology of perception. New York: Humanities Press.

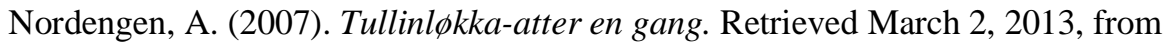

http://www.minervanett.no/tullinlkka-atter-en-gang/

Ranciére, J. (2012). Sanselighetens politikk. Oslo: Cappelen Damm.

Ranciére, J. (2004). Problems and transformations in critical art. In C. Bishop, (Ed.), Participation. Documents of contemporary art. London: Whitechapel Gallery.

Riegger, H. (2010). Primitive pottery. In G. Adamson, (Ed.). (2010). The craft reader (pp. 34-39). New York: Van Nostrand Reinhold Company

Sigsgaard, J., Varnhild, I. (1982). Det legede vi med: gammelt legetøy in Danmark. København: Nyt Nordisk Forlag Arnold Busck.

Tin, M. (2011). Spilleregler og spillerom: tradisjonens estetikk. Oslo: Novus Forlag.

Vetlesen, A. J. (2009). Frihetens forvandling: essays og artikler 2002-2008. Oslo: Universitetsforlaget.

InFormation 